\title{
PENGEMBANGAN PERANGKAT LUNAK GENERATE FILE DATA KEHADIRAN PEGAWAI UNIVERSITAS PALANGKA RAYA
}

\author{
Development of Software Generate Recording File Attendance Data of Universitas \\ Palangka Raya
}

\author{
Putu Bagus Adidyana \\ Anugrah Putra* \\ Viktor Handrianus \\ Pranatawijaya \\ Widiatry \\ Nova Noor Kamala Sari
}

Universitas Palangka Raya, Palangka Raya, Central Kalimantan, Indonesia

*email: putubagus@it.upr.ac.id

Kata Kunci:
Generate File
Waterfall
DFD
ERD

\section{Keywords: \\ Generate File \\ Waterfall \\ DFD \\ $E R D$}

\section{Accepted}

January 2019

\section{Published}

June 2019

\begin{abstract}
Abstrak
Ilmu pengetahuan dan teknologi mengalami perkembangan yang sangat pesat, salah satunya pada bidang aplikasi web yang perkembangannya semakin pesat sejak munculnya teknologi internet. Bagian Kepegawaian Universitas Palangka Raya telah menggunakan aplikasi dalam mengelola data pegawai, salah satunya adalah daftar kehadiran pegawai. Namun, dalam pengelolaannya masih kurang efisien karena staf dari bagian kepegawaian tidak bisa langsung memasukan status kehadiran pegawai seperti cuti, ijin dan sakit secara langsung pada pengolah data presensi karena harus menunggu pengambilan data dari mesin presensi elektronik di akhir bulan sehingga proses pembuatan rekapitulasi presensi berjalan lambat. Pengembangan perangkat lunak generate file data kehadiran pegawai Universitas Palangka Raya menggunakan metode pengembangan perangkat lunak Waterfall. Tahap pertama yang dilakukan adalah melakukan analisis kebutuhan dari sistem yang dibuat meliputi studi kepustakaan, pengumpulan data, konsultasi, dan perancangan. Berdasarkan analisis tersebut maka dibuatlah rancangan sistem yang menggunakan Data Flow Diagram (DFD), dan Entity Relationship Diagram (ERD), sebagai desain sistem yang akan dibuat. Tahap selanjutnya adalah penulisan kode program. Pada penulisan kode program bahasa pemrograman yang digunakan adalah HTML, CSS dan Java Script sebagai desain interface yang didukung oleh bahasa pemorograman PHP dan Mysql untuk penyimpanan dan pertukaran data. Pada tahapan selanjutnya dilakukan testing untuk menguji fungsionalitas dari aplikasi yang telah dibuat menggunakan metode blackbox. Perangkat lunak ini akan menjadi alat untuk menggenerate file data kehadiran pegawai Universitas Palangka Raya.
\end{abstract}

\begin{abstract}
Science and technology are experiencing very rapid development, one of them in the field of web applications whose growth has been increasing rapidly. Staffing Department of Universitas Palangka Raya has used applications to manage employee data, one of them is the employee attendance list. However, the management is still not efficient because staff from the staffing department cannot directly enter employee attendance status such as leave, permission, and illness directly on attendance data processors because they have to wait for data retrieval from the electronic attendance machine at the end of the month so that the process of making attendance recapitulation runs slowly. Software development in generating a file of the attendance data of Universitas Palangka Raya employees using the Waterfall software development method. The first step is to carry out a needs analysis of the system created, including library research, data collection, consultation, and design. Based on this analysis, the system design was created that uses Data Flow Diagrams, and Entity Relationship Diagrams, as the system design that will be created. The next step is writing the program code. In writing program code, the programming languages used are HTML, CSS, and JavaScript as interface designs supported by PHP and MySQL programming languages for data storage and exchange. In the next step, testing is done to test the functionality of the application that has been made using the black box method. This software will be a tool to generate files on attendance data for Universitas Palangka Raya employees.
\end{abstract} Palangkaraya. This is Open Access article under the CC-BY-SA License (http://creativecommons.org/licenses/by-sa/4.0/). DOI: https://doi.org//0.33084/anterior.v18i2.809.

\section{PENDAHULUAN}

Pada perkembangan teknologi yang pesat ini akses informasi dan pengolahan data semakin maju. Apalagi semenjak ditemukannya komputer yang semakin memudahkan pekerjaan manusia. Sehingga tidak mengherankan lagi jika banyak perkantoran maupun 
instansi yang beralih dari sistem manual dan mulai menggunakan computer (Ngafifi, 20l4).

Komputer sangat mempermudah pekerjaan manusia karena didalamnya terdapat berbagai macam perangkat lunak aplikasi yang membantu. Aplikasi adalah satu unit perangkat lunak yang sengaja dibuat untuk memenuhi kebutuhan akan berbagai aktivitas ataupun pekerjaan, seperti pelayanan masyarakat, game dan aktivitas lainnya yang dilakukan manusia. Saat ini banyak perkantoran atau instansi yang menggunakan aplikasi untuk bekerja dan memproses pengolahan data sehingga lebih cepat dan efisien (Pramana, 2012; Putra, 2009).

Salah satu yang menggunakan aplikasi dalam melakukan pekerjaannya adalah Bagian Kepegawaian Universitas Palangka Raya yang bertugas mengelola data pegawai, salah satunya adalah daftar kehadiran pegawai. Namun dalam pengelolaannya masih kurang efisien karena staf dari bagian kepegawaian tidak bisa langsung memasukan status kehadiran pegawai seperti cuti, izin dan sakit secara langsung pada pengolah data kehadiran karena harus menunggu pengambilan data dari mesin absen elektronik di akhir bulan sehingga proses pembuatan rekab kehadiran pegawai berjalan lambat (Ningsih \& Fibriany, 2018). Keterlambatan pengolahan data kehadiran pegawai menjadi salah satu pemicu terlambatnya pembayaran gaji dan uang lauk pauk di lingkungan Universitas Palangka Raya. Oleh karena itu diperlukan perangkat lunak pengolah data kehadiran pegawai sehingga staff bagian kepegawaian dapat langsung memasukan status kehadiran pegawai jauh-jauh hari tanpa harus menunggu data kehadiran dari mesin diambil dan secara otomatis membuat laporan rekab absen pegawai.

Sehubungan dengan pemanfaatan website, peneliti sebelumnya juga telah melakukan penelitian untuk merancang dan bangun media pembelajaran bagi murid Sekolah Menengah Pertama Luar Biasa (SMPLB) I Palangka Raya (Putra et al., 2018) serta analisis dan desain website monitoring konsultasi Bimbingan Kartu
Rencana Studi (KRS) (Putra et al., 2017a). Selain itu, sebelumnya penulis juga telah melakukan Pengembangan perangkat lunak generate file untuk migrasi data EPSBED ke format table Feeder PDDIKTI (Pranatawijaya et al., 2016) serta pengembangan perangkat lunak generate file akun Uang Kuliah Tunggal (UKT) Universitas Palangka Raya (Pranatawijaya et al., 2018) dapat digunakan sebagai dasar dalam pembuatan otomatisasi pembuatan informasi berdasarkan data-data tertentu. Penulis juga berpengalaman dalam mendesain rancang bangun sistem informasi pencarian data mahasiswa dan dosen pada Fakultas Hukum Universitas Palangka Raya (Putra et al., 20l7b) memberikan cara untuk pengelolaan data yang akan digunakan untuk pembelajaran dan pemahaman dalam teknik searching data. Sehingga, tujuan penelitian ini adalah untuk pengembangan perangkat lunak generate file data kehadiran pegawai Universitas Palangka Raya sehingga dapat menjadi suatu pondasi untuk mengimplementasikan sistem tersebut nantinya.

\section{METODOLOGI}

Metode Pengembangan perangkat lunak yang digunakan adalah metode Waterfall. Menurut Sommervile (20II) waterfall model adalah sebuah contoh dari proses perencanaan, di mana semua proses kegiatan harus terlebih dahulu direncanakan dan dijadwalkan.

\section{Studi Pustaka dan Observasi}

Metode ini melakukan studi pustaka terhadap buku, jurnal ilmiah nasional dan internasional sebagai pendukung dalam penelitian. Observasi dilakukan untuk mengambil data-data untuk titik dan berapa besar radius yang diperlukan untuk menandakan suatu ruangan yang nantinya akan dijadikan area untuk mengeluarkan informasi.

\section{Analisis Sistem}

Proses pencarian kebutuhan difokuskan pada software untuk mengetahui sifat dari website yang akan dibuat, pemodelan proses bisnis menggunakan 
Data Flow Diagram (DFD) dan Entity Relationship Diagram (ERD).

Data Flow Diagram merupakan diagram yang menggambarkan alir data dalam suatu entitas ke sistem atau sistem ke entitas. Data Flow Diagram juga dapat diartikan sebagai suatu model logika data atau proses yang dibuat untuk menggambarkan asal data, dan kemana tujuan data yang keluar dari sistem, dimana data disimpan, proses apa yang menghasilkan data tersebut, dan interaksi antara data yang tersimpan, dan proses yang dikenakan pada data tersebut (Kristanto ,2008). Entity Relationship Diagram adalah diagram yang menghubungkan antar entitas di dalam penyusunan/perancangan basis data. Tujuan dari ERD adalah untuk menunjukkan objek data dan relationship yang ada pada objek tersebut. Selain itu, ERD juga digunakan untuk mengontrol dan memonitor sistem basis data (Btoush \& Hammad, 2015).

\section{Desain Sistem}

Proses ini digunakan untuk membuat blueprint software seperti, perancangan basis data dan perancangan antarmuka (interface).

4. Implementasi

Proses ini akan dilakukan pembuatan perangkat lunak sesuai dengan perancangan basis data dan antar muka yang telah dilakukan pada tahap sebelumnya.

5. Pengujian Sistem

Proses pengujian akan dilakukan dengan Blackbox Testing yang disertai dengan melakukan simulasi data. Pengujian Black Box adalah pengujian aspek fundamental sistem tanpa memperhatikan struktur logika internal perangkat lunak. Metode ini digunakan untuk mengetahui apakah perangkat lunak berfungsi dengan benar. Pengujian black box merupakan metode perancangan data uji yang didasarkan pada spesifikasi perangkat lunak. Data uji dieksekusi pada perangkat lunak dan kemudian keluar dari perangkat lunak dicek apakah telah sesuai yang diharapkan. Tujuan utama pengujian haruslah untuk mengekspos kesalahan dalam perangkat lunak dan untuk menghindari potensi kegagalan (Bhasin et al., 2014).

\section{HASIL DAN PEMBAHASAN}

Untuk merancang sistem digunakan pemodelan data yang sesuai untuk menggambarkan proses atau alur yang terjadi dalam perangkat lunak generate file data kehadiran pegawai Universitas Palangka Raya. Pemodelan data pada aplikasi ini adalah menggunakan beberapa diagram data yaitu DFD dan ERD, Selain itu juga dilakukan desain Tabel Database, dan Desain Interface (Perancangan Antar Muka). Desain Diagram Konteks tersaji pada Gambar I, sedangkan desain Diagram DFD Level I tersaji pada Gambar 2 berikut.

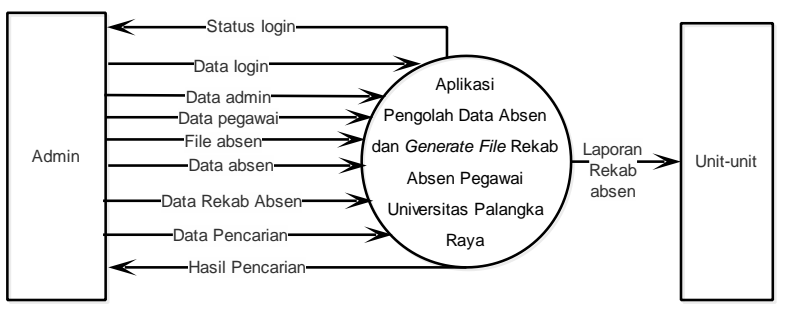

Gambar I. Diagram Konteks

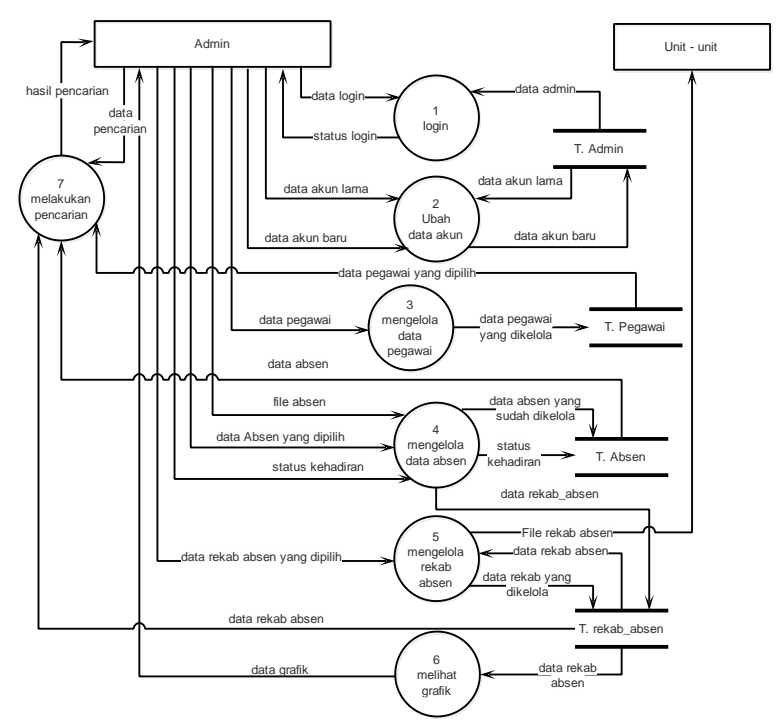

Gambar 2. DFD Level I 
Dari gambar DFD diatas dapat diketahui bahwa aplikasi ini memiliki tujuh buah proses yang dikerjakan oleh admin yaitu proses login, ubah data akun, mengelola data pegawai, mengelola data absen, mengelola data rekab absen dan melihat grafik serta melakukan pencarian. Untuk unit-unit penerima laporan rekab absen adalah Unit - unit yang ada pada Universitas Palangka Raya yaitu unit BOPT, BUK, BAKP, PNPB, FKIP, FAPERTA, FEB, Fak.Teknik, Fak. Kedokteran, FEB, Fak. MIPA, FISIP, Fak.Hukum, Pascasarjana, LP3MP, LPPM, UPT Bahasa, UPT. Gambut (CIMTROP), UPT TIK, UPT Perpustakaan dan Lab. Terpadu. Diagram DFD Level 2 khusus pengelolaan Absensi disajikan pada Gambar 3.

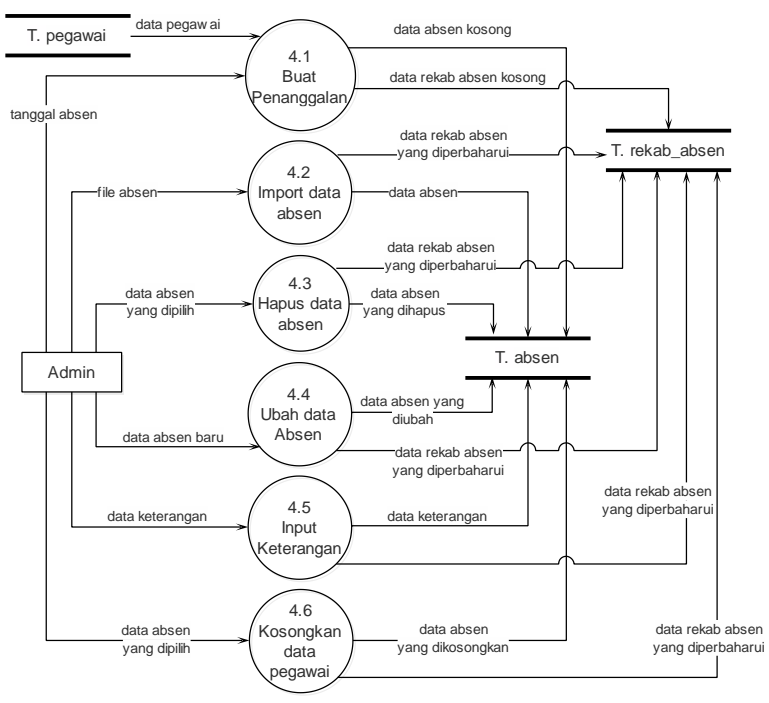

Gambar 3. DFD Level 2 Kelola Absen

Gambar diatas menggambarkan proses admin mengelola data kehadiran yang terdiri dari enam buah proses yaitu membuat penanggalan, import data absen, hapus data absen, ubah data absen, input keterangan dimana semua proses dilakukan oleh admin dengan memberikan id_pegawai, tanggal awal dan lamanya serta keterangannya dan disimpan pada tabel absen dan perubahan data ini akan disimpan di tabel absen secara otomatis sistem akan memperbaharui data rekab absen. Diagram DFD Level 2 Kelola Rekap Absen disajikan pada Gambar 4.

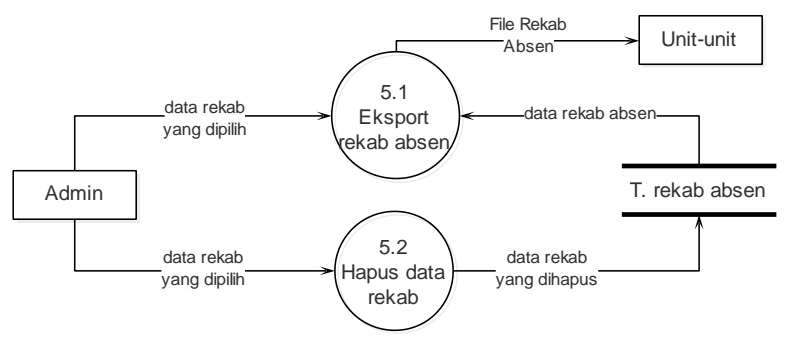

Gambar 4. DFD Level 2 Kelola Rekap Absen

Gambar diatas menggambarkan proses admin mengelola rekab absen yaitu proses eksport data rekab absen yang berfungsi untuk menggenerate file absen berformat "xls" untuk kemudian diberikan ke unit-unit yang ada di Universitas Palangka Raya. Diagram ERD untuk rekap absen disajikan pada Gambar 5 .

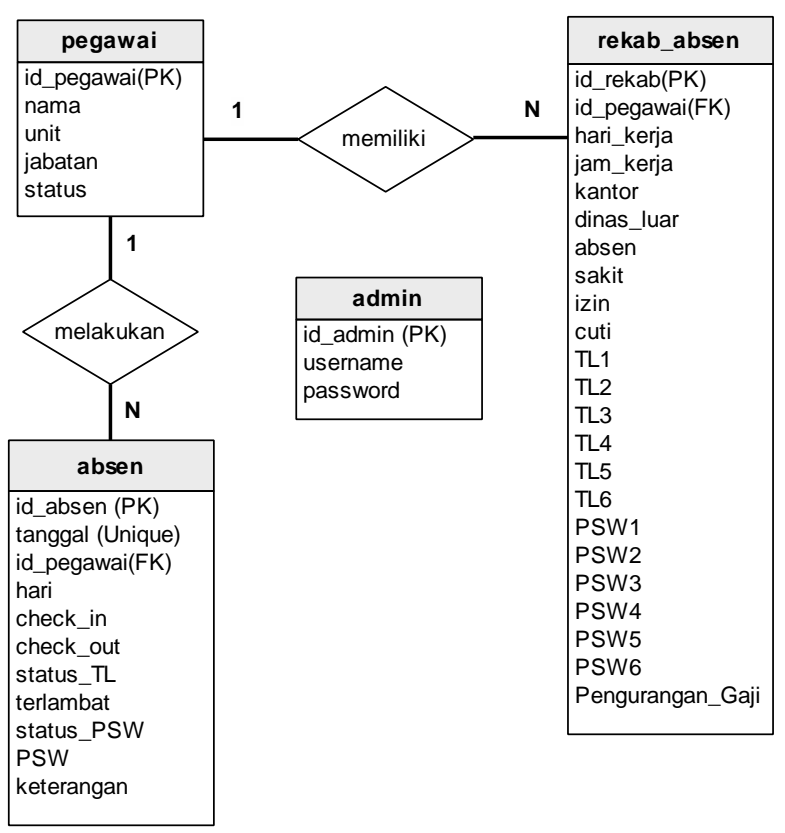

Gambar 5. Entity Relationship Diagram

Untuk perancangan antarmuka digunakan dua metode pemrograman, aplikasi server menggunakan Database MySQL dan aplikasi website menggunakan PHP. Adapun implementasi halaman login yang dirancang disajikan pada Gambar 6, sedangkan halaman Beranda, halaman Absen, serta halaman Generate Absen secara berturutturut disajikan pada Gambar 7 sampai Gambar 9 berikut. 


\section{Kepegawaian UPR}

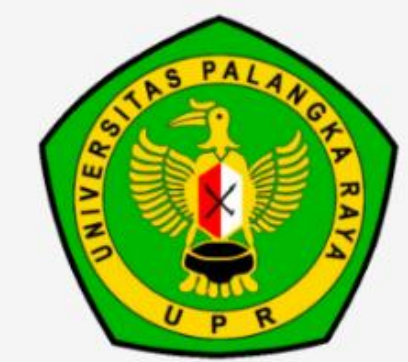

Masukan Username

Masukan Pas Please fill out this field.

\section{Login}

Gambar 6. Implementasi Halaman Login

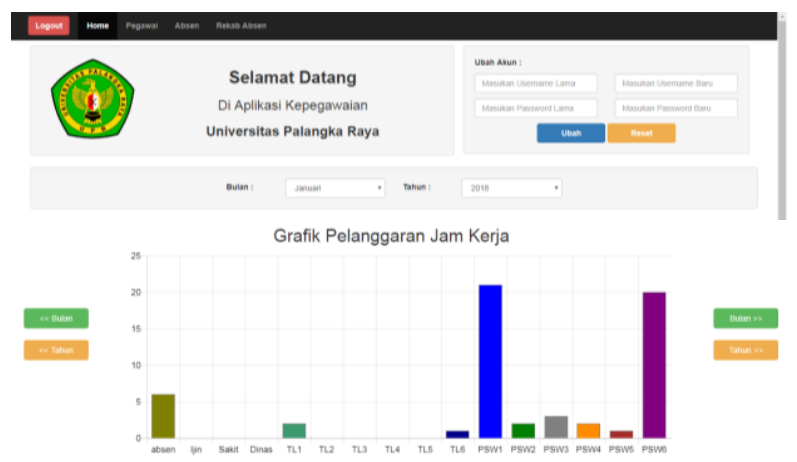

Gambar 7. Implementasi Beranda

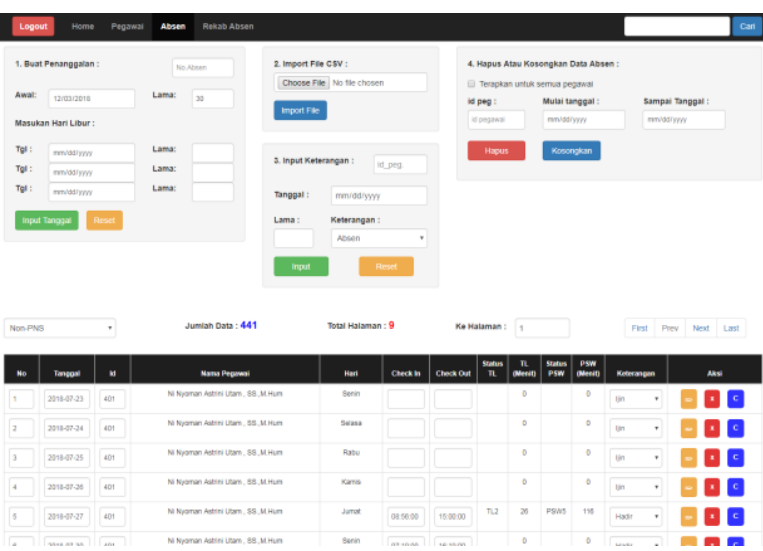

Gambar 8. Implementasi Halaman Absen

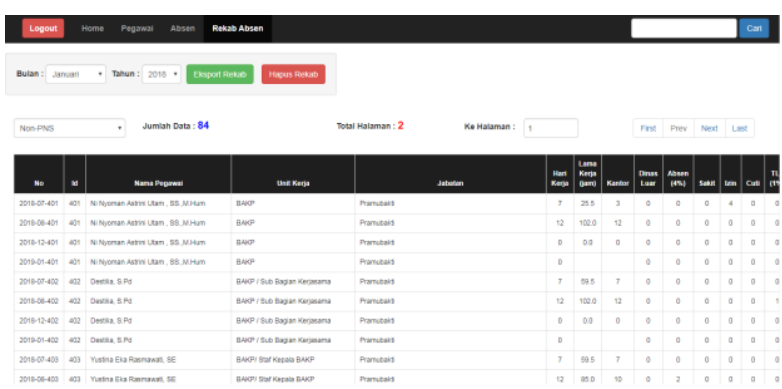

Gambar 9. Implementasi Halaman Generate Absen

Pengujian pada perangkat lunak ini menggunakan pengujian blackbox. Pengujian blackbox berfokus pada persyaratan fungsional perangkat lunak. Pengujian bermaksud untuk mengetahui perangkat lunak yang dibuat sudah memenuhi kriteria yang sesuai dengan tujuan perancangan perangkat lunak tersebut. Berikut ini adalah hasil pengujian sistem menggunakan metode blackbox.

Tabel I. Pengujian Halaman Absen

\begin{tabular}{|c|c|c|c|c|}
\hline $\begin{array}{l}\mathrm{N} \\
\mathrm{o}\end{array}$ & Aksi & $\begin{array}{l}\text { Hasil Yang } \\
\text { Diharapkan }\end{array}$ & $\begin{array}{c}\text { Hasil } \\
\text { Keluaran }\end{array}$ & Ket \\
\hline $\mathrm{I}$ & $\begin{array}{l}\text { Membuat } \\
\text { Penanggalan } \\
\text { dengan } \\
\text { memasukan } \\
\text { tanggal awal, } \\
\text { jumlah hari, } \\
\text { memasukan } \\
\text { tanggal libur serta } \\
\text { jumlah hari nya } \\
\text { pada inputan } \\
\text { dengan benar. Lalu } \\
\text { klik tombol "Input } \\
\text { Tanggal" }\end{array}$ & $\begin{array}{l}\text { Proses } \\
\text { Penanggalan } \\
\text { berhasil } \\
\text { dengan } \\
\text { Menampilkan } \\
\text { Pesan "Proses } \\
\text { Penanggalan } \\
\text { Berhasil" dan } \\
\text { berhasil } \\
\text { secara } \\
\text { otomatis } \\
\text { membuat } \\
\text { id_rekab pada } \\
\text { tabel } \\
\text { rekab_absen }\end{array}$ & $\begin{array}{l}\text { Proses } \\
\text { Penanggalan } \\
\text { berhasil } \\
\text { dengan } \\
\text { Menampilkan } \\
\text { Pesan "Proses } \\
\text { Penanggalan } \\
\text { Berhasil" dan } \\
\text { berhasil } \\
\text { secara } \\
\text { otomatis } \\
\text { membuat } \\
\text { id_rekab pada } \\
\text { tabel } \\
\text { rekab_absen }\end{array}$ & $\sqrt{ }$ \\
\hline 2 & $\begin{array}{l}\text { Membuat } \\
\text { Penanggalan } \\
\text { dengan } \\
\text { memasukan } \\
\text { tanggal awal, } \\
\text { jumlah hari, } \\
\text { memasukan } \\
\text { tanggal libur serta } \\
\text { jumlah hari nya } \\
\text { pada inputan } \\
\text { dengan salah. Lalu } \\
\text { klik tombol "Input } \\
\text { Tanggal" }\end{array}$ & $\begin{array}{l}\text { Proses } \\
\text { Penanggalan } \\
\text { berhasil } \\
\text { dengan } \\
\text { Menampilkan } \\
\text { Pesan "Maaf.. } \\
\text { Tanggal Sudah } \\
\text { Digunakan" }\end{array}$ & $\begin{array}{l}\text { Proses } \\
\text { Penanggalan } \\
\text { berhasil } \\
\text { dengan } \\
\text { Menampilkan } \\
\text { Pesan "Maaf.. } \\
\text { Tanggal Sudah } \\
\text { Digunakan" }\end{array}$ & $\checkmark$ \\
\hline 3 & $\begin{array}{l}\text { Melakukan proses } \\
\text { import file "csv" } \\
\text { data Absen dan } \\
\text { tekan tombol } \\
\text { "Import File" }\end{array}$ & $\begin{array}{l}\text { File CSV } \\
\text { absen berhasil } \\
\text { diimport dan } \\
\text { memperbahar } \\
\text { ui data absen } \\
\text { dengan } \\
\text { menampilkan } \\
\text { Pesan "File } \\
\text { Sudah } \\
\text { Berhasil Di- } \\
\text { Import" }\end{array}$ & $\begin{array}{l}\text { File CSV } \\
\text { absen berhasil } \\
\text { diimport dan } \\
\text { memperbahar } \\
\text { ui data absen } \\
\text { dengan } \\
\text { menampilkan } \\
\text { Pesan "File } \\
\text { Sudah } \\
\text { Berhasil Di- } \\
\text { Import" }\end{array}$ & $\checkmark$ \\
\hline
\end{tabular}




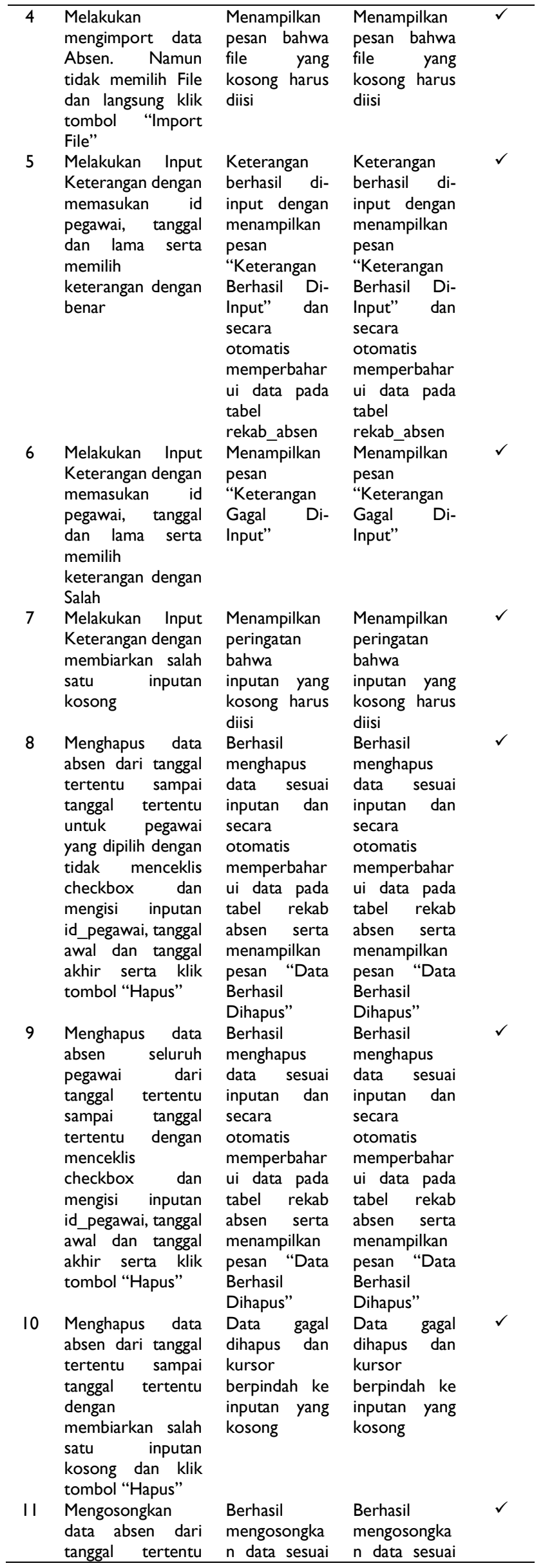

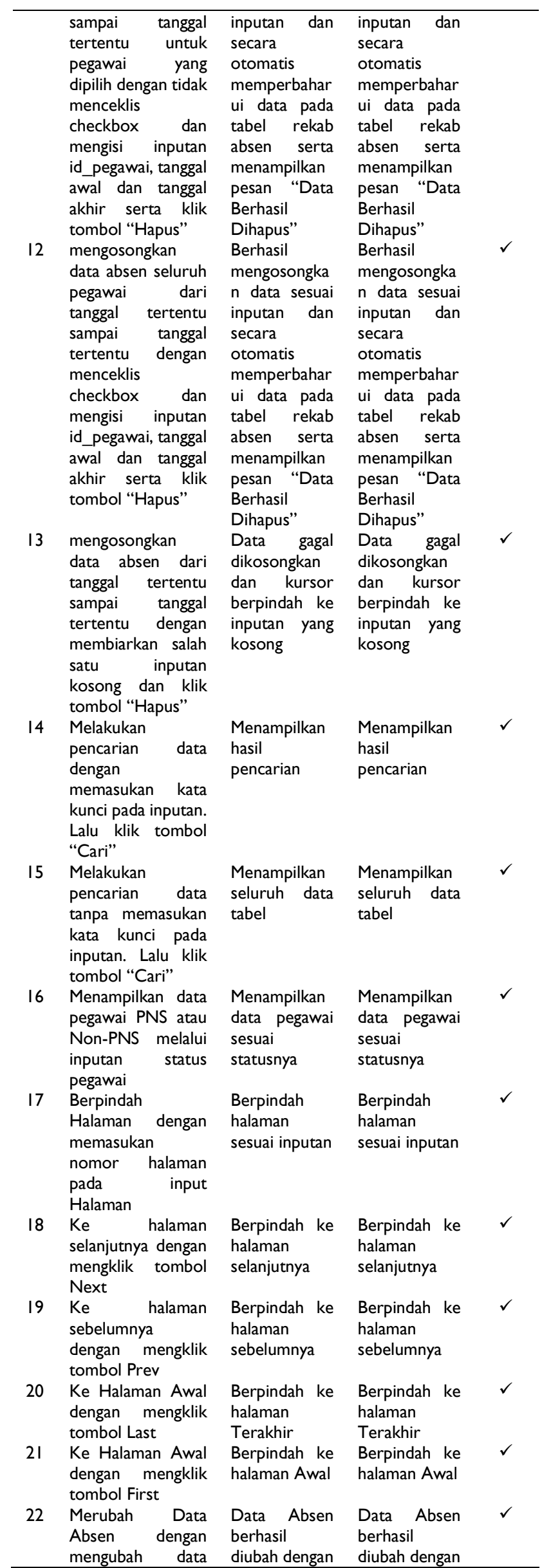




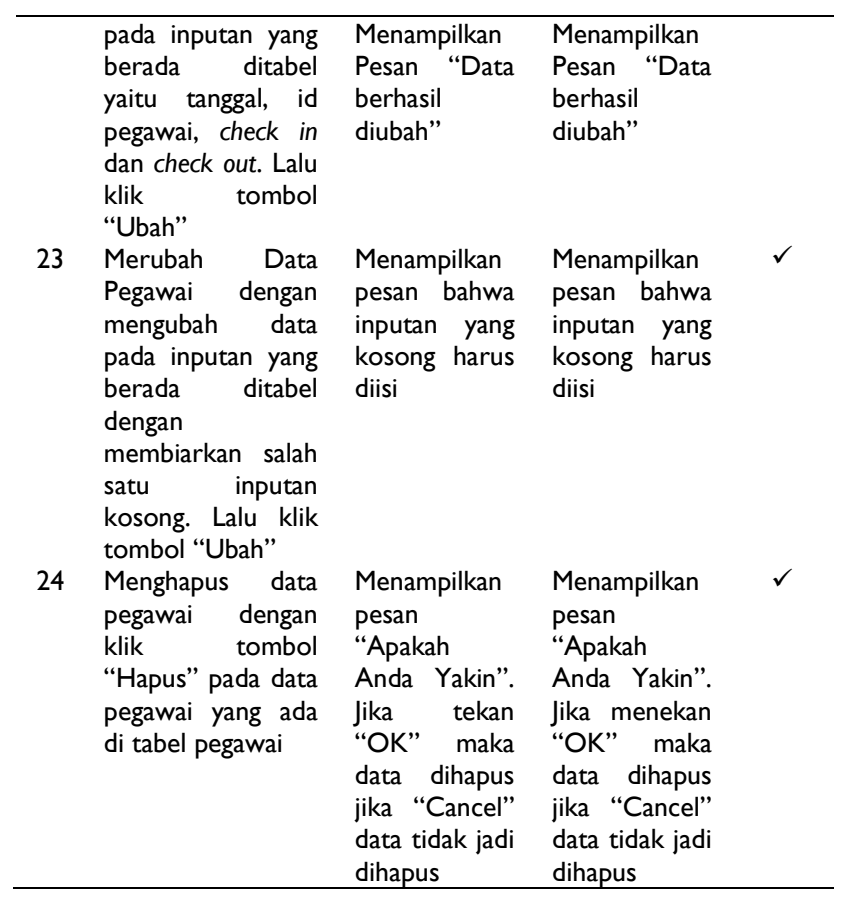

\section{KESIMPULAN}

Dalam pengembangan perangkat lunak generte data kehadiran pegawai Universitas Palangka Raya digunakan metode pengembangan perangkat lunak Waterfall. Tahap pertama yang dilakukan adalah melakukan analisis kebutuhan dari sistem yang dibuat meliputi studi kepustakaan, pengumpulan data, konsultasi, dan perancangan. Dari analisis tersebut maka dibuatlah rancangan sistem yang menggunakan DFD dan ERD sebagai desain sistem yang akan dibuat. Setelah dilakukan perancangan sistem maka selanjutnya adalah tahap penulisan kode program. Pada penulisan kode program bahasa pemrograman yang digunakan adalah HTML, CSS dan JavaScript sebagai desain interface yang didukung oleh bahasa pemorograman PHP dan MySQL untuk penyimpanan dan pertukaran data. Pada tahapan selanjutnya dilakukan testing untuk menguji fungsionalitas dari aplikasi yang telah dibuat menggunakan metode blackbox. Untuk pengembangan kedepannya dapat diimplementasikan pada perangkat mobile untuk halaman akun pegawai.

\section{REFERENSI}

Btoush, E.S. \& Hammad, M.M, 20I5. Generating ER diagrams from requirement specifications based on natural language processing. International Journal of Database Theory and Application, 8, 61-70.

Bhasin, H., Khanna, E, \& Sudha. 20I4. Black Box Testing based on Requirement Analysis and Design Specifications. International Journal of Computer Applications, 87, 36-40.

Ngafifi, M. 2014. Kemajuan Teknologi dan Pola Hidup Manusia dalam Perspektif Sosial Budaya. Jurnal Pembangunan Pendidikan: Fondasi dan Aplikasi, 2, 33-47.

Ningsih, A.F. \& Fibriany, F.W. 2018. Sistem Informasi Ketidakhadiran Izin dan Cuti Berbasis Web pada BPSDM Kemendagri. IJCIT (Indonesian Journal on Computer and Information Technology), 3, 138-147.

Pramana, H.W. 2012. Aplikasi Inventory Berbasis Access 2003. Jakarta: Elex Media Komputindo.

Pranatawijaya, V.H., Putra, P.B.A.A., Widiatry, \& Sari, N.N.K. 2018. Pengembangan Perangkat Lunak Generate File Akun Uang Kuliah Tunggal (UKT) Universitas Palangka Raya. Jurnal Saintekom: Sains, Teknologi, Komputer dan Manajemen, 8, I66-I78.

Pranatawijaya, V.H., Putra, P.B.A.A., \& Gunawan, V.A. 2016. Pengembangan Perangkat Lunak Generate File Untuk Migrasi Data EPSBED Ke Format Table Feeder PDDIKTI. Jurnal Saintekom: Sains, Teknologi, Komputer dan Manajemen, 6, I-II.

Putra, P.B.A.A., Pranatawijaya, V.H., \& Sinana, A.R. 2018. Rancang Bangun Media Pembelajaran bagi Murid Sekolah Menengah Pertama Luar Biasa (SMPLB) I Palangka Raya. Anterior Jurnal, 18, 79-85.

Putra, P.B.A.A., Pranatawijaya, V.H., Widiatry, \& Lisa. 2017a. Rancang Bangun Sistem Informasi Pencarian Data Mahasiswa dan Dosen pada Fakultas Hukum Universitas Palangka Raya. Jurnal Teknologi Informasi, I I, 36-45.

Putra, P.B.A.A., Sari, N.N.K., \& Pranatawijaya, V.H. 20l7b. Analisis dan Desain Website Monitoring Konsultasi Bimbingan Kartu Rencana Studi (KRS). Jurnal Teknologi Informasi, II, 58-68. 
Putra, A. 2009. Peningkatan Sistem Pelayanan dengan Penerapan Model Sistem Informasi Manajemen Satu Atap. JSI: Jurnal Sistem Informasi, I, 23-36.

Sommerville, I. 20I I. Software Engineering. $9^{\text {th }}$ Edition. New Jersey: Pearson Education. 